\title{
Effect of Fertilizer Sources on Soil Organic Matter and Soil Microbial Population in Broccoli Field
}

\author{
Salina Panta ${ }^{1 *}$, Purushottam Subedi ${ }^{2}$ and Indira Bhattarai ${ }^{1}$ \\ ${ }^{1}$ Agriculture and Forestry University, Chitwan, Nepal \\ ${ }^{2}$ Center for Crop Development and Agro-Biodiversity Conservation, Lalitpur, \\ Nepal \\ *Corresponding Author: Salina Panta, Agriculture and Forestry University, \\ Chitwan, Nepal.
}

Received: May 11, 2020

Published: May 29, 2020

(C) All rights are reserved by Salina Panta., et al.

\begin{abstract}
Soil microbes show positive ecological interactions which promote nutrient recycling, decomposition and plant growth. To study the effect of different fertilizer sources on soil organic matter and soil microbial population in broccoli field, an experiment was conducted at Agriculture and Forestry University, Chitwan, Nepal from September 2015 to February 2016. The research consisted of ten treatments viz; recommended NPK fertilizer, Farmyard manure (FYM), Vermicompost (VC), Cow urine (CU), Bio organic fertilizer (BOF), (NPK 50\% + FYM 50\%), (FYM 50\% + CU 50\%), (FYM 50\% + VC 50\%), (FYM 50\% + BOF 50\%) and (25\% FYM + 25\% VC+ 25\% $\mathrm{CU}+25 \% \mathrm{BOF}$ ) in randomized complete block design replicated three times. The study revealed that highest soil organic matter was recorded in FYM (50\%) + vermicompost (50\%) treatment (2.85\%) which remained statistically similar with all other organic treatments. The recommended NPK treatment had significantly lowest SOM (2.06\%). The highest bacteria population (43.6 x $\left.10^{7} \mathrm{cfu} / \mathrm{g}\right)$ and highest fungi population $\left(11.0 \times 10^{6} \mathrm{cfu} / \mathrm{g}\right)$ were observed in treatment consisting all organic fertilizer sources $(25 \% \mathrm{FYM}+25 \%$ $\mathrm{VC}+25 \% \mathrm{CU}+25 \%$ BOF). In recommended NPK treatment, the bacteria and fungi population were $4.10 \times 10^{7} \mathrm{cfu} / \mathrm{g}$ and $7.1 \times 10^{6}$ $\mathrm{cfu} / \mathrm{g}$ in $10^{-6}$ dilution respectively. But, in the treatments consisting organic fertilizer sources, bacteria population ranged from $2.93 \mathrm{x}$ $10^{7} \mathrm{cfu} / \mathrm{g}$ to $43.6 \times 10^{7} \mathrm{cfu} / \mathrm{g}$ and fungi population ranged from $7.33 \times 10^{5} \mathrm{cfu} / \mathrm{g}$ to $11.0 \times 10^{6} \mathrm{cfu} / \mathrm{g}$ in the same dilution respectively. Positive regression relation was also observed in between soil organic matter and soil microbes. Therefore, organic fertilizer sources supported for soil organic matter enrichment and promotion of bacteria and fungi population in the soil in comparison to chemical fertilizers.
\end{abstract}

Keywords: Soil Microbes; Soil Organic Matter; Colony Forming Units; Organic Fertilizer

\section{Introduction}

Broccoli (Brassica oleracea L. var. italica) is one of the important vegetables belonging to family Brassicaceae.

It contains abundant vitamins and minerals such as vitamin A and $\mathrm{C}$, carotenoids, fiber, calcium, and folic acid [1]. Broccoli and other brassica vegetables have high content of glucosinolates which has anti-cancer properties [2]. Soil hosts bacteria, fungi, other microbes and animals. Numbers of microorganism may vary in and between different soil types and conditions, with bacteria being the most numerous. Bacterial counts in different soils ranged from $4 \times 10^{6}$ to $2 \times 10^{9}$ per gram of dry soil [3]. Similarly, soil fungi are also most abundant group of soil microorganisms, on a mass basis, and their biomass ranges from 100 to 1500 grams $/ \mathrm{m}^{2}$ of soil [4]. Growth of microbes and their action on soils are dependent on the interaction between plant species and soil [5]. Bacterial community composition results from the interaction between soil type, plant species and its rhizosphere localization [6]. Soil

Citation: Salina Panta., et al."Effect of Fertilizer Sources on Soil Organic Matter and Soil Microbial Population in Broccoli Field". Acta Scientific Agriculture 4.6 (2020): 36-44. 
microbes, mostly fungi and bacteria are active participants in the ecosystems and perform organic matter decomposition, liberating and recycling chemical nutrients, formation of soil aggregates, detoxification of organic toxicants, promotion of plant growth etc. $[7,8]$. They show the positive ecological interactions that promote plant growth. The growth of soil microbes is usually carbon limited, so the high amounts of sugars, amino acids and organic acids that plants deposit into the rhizosphere represent a valuable nutrition source [9].

The increasing awareness of the harmful effects of indiscriminate use of chemical fertilizers and pesticides has led to the adoption of organic fertilizers and manures. Organic manure can serve as alternative practice to mineral fertilizers for improving soil structure [10] and microbial biomass [11]. It is also a source of food for the innumerable number of microorganisms and creatures like earthworm which break down the organic matter into plant available nutrients, which are easily absorbed by the plants. Soil organic matter improves soil texture, increases ion exchange capacity of soil, increases soil microbial populations and activity, improves moisture-holding capacity of the soil and enhances soil fertility [12]. Soil organic matter consists of broad groups of substances, often called pools that vary in their rates of decomposition and functions. One of the most important pools of organic matter is the microbial biomass. Although the size of the microbial biomass is relatively small, the nutrients within this pool are recycled rapidly within the soil profile, perhaps 8 to 10 times per year [13]. The microbial biomass is a relatively available reservoir of plant nutrients such as nitrogen and phosphorus [14].

Therefore, an experiment was carried out to find the effects of different fertilizer sources on soil organic matter and microbial population in a broccoli field at Agriculture and Forestry University, Rampur, Chitwan during 2015/16.

\section{Methodology}

The study was conducted in Agriculture and Forestry University, Rampur, Chitwan (from September 2015 to February 2016) in randomized complete block design (RCBD) with ten treatments (Table 1) and was replicated thrice. The physico-chemical properties of field soil (30 $\mathrm{cm}$ depth) before the experimentation were as presented in the table 2 . Amounts of fertilizers for each treatments were calculated based on recommended dose of fertilizer for broc- coli [15]. Urea was applied in two equal splits first as basal and second as top dress at 30 days after transplanting (DAT). In case of cow urine, at first, it was left for two weeks for fermentation and then applied over the soil surface in 7 days interval diluted with water in the ratio of $1: 2[16,17]$. Each plot had $5.4 \mathrm{~m}^{2}$ area with 20 plants planted in $60 \times 45$ crop spacing. Likewise, soil organic matter (SOM) was measured for each plot after the crop harvest. Details of experimental field's soil and nutrient contents of different organic fertilizers used in experiment are given in table 2 and 3 respectively.

To determine the soil microbial population, serial dilution method was used. This method is used for plating and enumerating live microorganisms in a given population. In this technique, plating was done and determination of the total number of bacteria and fungi was done in the original solution by counting the number of colony forming units (cfu) and comparing them to the dilution factor [20]. Each CFU represents a bacterium that was present in the diluted sample. For bacteria, Nutrient Agar media was used with pH 7.0 and Czapek dox media with pH 7.3 was used for fungi. Compositions used to prepare these media for bacteria and fungi are given in the table 4 and 5 respectively.

\begin{tabular}{|c|c|}
\hline $\begin{array}{l}\text { Treatment symbols and } \\
\text { combinations }\end{array}$ & Amount of fertilizers* \\
\hline T1: Recommended NPK & $\begin{array}{c}\text { 137g urea, 207.67g DAP, } \\
70.76 \mathrm{~g} \text { potash }\end{array}$ \\
\hline T2: NPK (50\%) + FYM (50\%) & $\begin{array}{c}\text { 68.5g urea, } 103.5 \mathrm{~g} \text { DAP, } 35 \mathrm{~g} \\
\text { potash, } 20 \mathrm{Kg} \text { FYM }\end{array}$ \\
\hline T3: FYM & $40 \mathrm{Kg}$ FYM \\
\hline T4: Vermicompost & $11 \mathrm{Kg}$ vermicompost \\
\hline T5: Cow urine & 20L. cow urine \\
\hline $\begin{array}{c}\text { T6: Bio organic fertilizer } \\
\text { (BOF) }\end{array}$ & $9 \mathrm{Kg} \mathrm{BOF}$ \\
\hline $\begin{array}{c}\text { T7: } 50 \% \text { FYM }+50 \% \text { cow } \\
\text { urine }\end{array}$ & $20 \mathrm{Kg} \mathrm{FYM}, 10 \mathrm{~L}$. cow urine \\
\hline $\begin{array}{c}\text { T8: } 50 \% \text { FYM + 50\% } \\
\text { vermicompost }\end{array}$ & $\begin{array}{c}20 \mathrm{Kg} \text { FYM, } 5.5 \mathrm{Kg} \\
\text { vermicompost }\end{array}$ \\
\hline T9: $50 \%$ FYM + 50\% BOF & 20 Kg FYM, 4.5 Kg BOF \\
\hline $\begin{array}{c}\text { T10: } 25 \% \mathrm{FYM}+25 \% \\
\text { Vermicompost }+25 \% \text { cow } \\
\text { urine }+25 \% \text { BOF }\end{array}$ & $\begin{array}{c}10 \mathrm{Kg} \mathrm{FYM}, 2.75 \mathrm{Kg} \\
\text { vermicompost, } 2.25 \mathrm{Kg} \mathrm{BOF} \text {, } \\
\text { 0.83L. cow urine }\end{array}$ \\
\hline
\end{tabular}

Table 1: Treatment symbols, combinations and amounts of fertilizers in each treatment.

Note: *Amounts of fertilizers per plot, urea was applied in two equal splits; first half as basal and second half as top dress at 30 days after transplanting. 


\begin{tabular}{|c|c|c|c|c|}
\hline S.N. & Properties & Average content & Category & Reference \\
\hline \multirow{4}{*}{1.} & Physical properties & & & \\
\hline & Sand (\%) & 72.1 & - & \\
\hline & Silt $(\%)$ & 22.8 & - & \\
\hline & Clay $(\%)$ & 5.1 & - & \\
\hline 2. & Textural class (USDA) & - & Sandy loam & [18] \\
\hline 3. & Bulk density & 1.41 & & \\
\hline \multirow{6}{*}{4.} & Chemical properties & & & \multirow{6}{*}{ [19] } \\
\hline & Soil pH & 6.4 & $\begin{array}{c}\text { Towards } \\
\text { neutral }\end{array}$ & \\
\hline & Soil organic matter (\%) & 2.65 & Medium & \\
\hline & Total nitrogen (\%) & 0.14 & Medium & \\
\hline & Available phosphorus (Kg/ha) & 17.33 & Medium & \\
\hline & Available potassium (Kg/ha) & 160.8 & Medium & \\
\hline
\end{tabular}

Table 2: Physico-chemical properties of the soil of the experimental site in Chitwan, Nepal, 2015/16.

\begin{tabular}{|c|c|c|c|c|}
\hline S.N. & $\begin{array}{c}\text { Organic } \\
\text { fertilizers }\end{array}$ & $\begin{array}{c}\text { Nitrogen } \\
\mathbf{( \% )}\end{array}$ & $\begin{array}{c}\text { Phosphorus } \\
\mathbf{( \% )}\end{array}$ & $\begin{array}{c}\text { Potash } \\
\mathbf{( \% )}\end{array}$ \\
\hline 1 & FYM & 0.65 & 0.51 & 1.05 \\
\hline 2 & $\begin{array}{c}\text { Vermicom- } \\
\text { post }\end{array}$ & 1.70 & 0.65 & 2.66 \\
\hline 3 & Cow urine & 0.90 & 0.45 & 1.95 \\
\hline 4 & BOF & 2.0 & 1.0 & 1.2 \\
\hline
\end{tabular}

Table 3: Nutrient content of different organic fertilizer sources used in experiment.

\begin{tabular}{|l|c|}
\hline \multicolumn{1}{|c|}{ Composition } & Amount \\
\hline Peptone & $5.0 \mathrm{~g}$ \\
\hline Beef extract & $3.0 \mathrm{~g}$ \\
\hline $\mathrm{NaCl}$ & $5.0 \mathrm{~g}$ \\
\hline Agar & $15 \mathrm{~g}$ \\
\hline Distilled water & $1000 \mathrm{ml}$ \\
\hline Yeast extract & $1.5 \mathrm{~g}$ \\
\hline
\end{tabular}

Table 4: The composition of Nutrient Agar Media [21].

\begin{tabular}{|c|c|}
\hline Composition & Amount \\
\hline Sodium Nitrate & $2 \mathrm{~g}$ \\
\hline Dipotassium hydrogen phosphate & $1.0 \mathrm{~g}$ \\
\hline Magnesium sulphate & $0.5 \mathrm{~g}$ \\
\hline Potassium chloride & $0.5 \mathrm{~g}$ \\
\hline Ferrous sulphate & $0.01 \mathrm{~g}$ \\
\hline Sucrose & $30 \mathrm{~g}$ \\
\hline Agar & $15 \mathrm{~g}$ \\
\hline Distilled water & $1000 \mathrm{ml}$ \\
\hline
\end{tabular}

Table 5: The composition of Czapek dox media [22].

After the respective incubation period, bacterial and fungal colonies in each plate were counted and microbial populations was determined per gram soil by multiplying the average count by dilution factor. The colony are formed by the viable microorganisms present in the soil sample. These are called Colony Forming Units (cfu). Fungal or Bacterial population or population in the given original sample is represented by no of cfu per ml of sample as given in the following formula [23]:

Number of cfu

Volume plated $(\mathrm{ml}) \times$ Dilution Factor 
Therefore, Bacterial population per gram of the soil= number of bacterial colonies $\times 10^{6}$

Fungal population per gram of the soil= number of fungal colonies $\times 10^{5}$.

\section{Data analysis}

The data collected in the experiment were statistically analyzed with GEN-STAT Version 4.0 statistical software program. Analysis of variance (ANOVA) was done on every measured parameter to

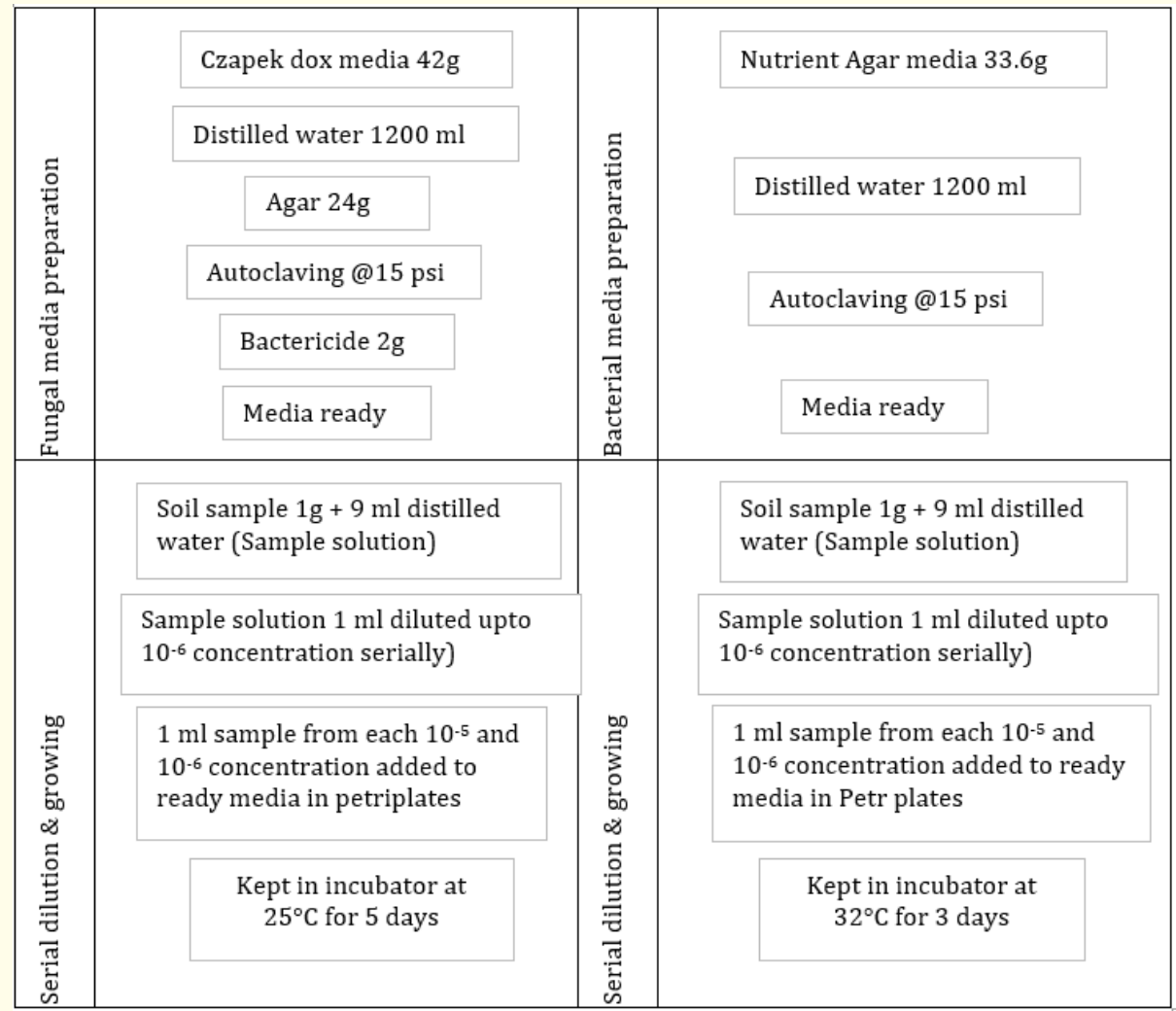

Figure 1: Schematic diagram for steps in media preparation and serial dilution and culturing procedure.

determine the significance of differences between means of treatments. Means for each parameter were separated by the Duncan's multiple range test (DMRT) and least significant difference (LSD) at $\mathrm{P} \leq 0.05$. Similarly, for the bacterial and fungal population, counting of colony forming units and calculations were carried for the comparison among the treatments.

\section{Results and Discussion}

\section{Soil organic matter}

The SOM is indicator of soil quality and fertility [24]. It is one of three soil components that are crucial for its physicochemical properties, such as its sorptive and buffer abilities as well as its biodiversity and biological activity [25]. This experiment showed that soil organic matter was found significantly influenced by the different fertilizer sources (Table 6). The highest SOM was recorded in FYM $(50 \%)+$ vermicompost $(50 \%)$ treatment $(2.85 \%)$. It remained statistically similar with all other treatments with sole and combined organic sources and statistically different with recommended NPK treatment (2.06\%). Concerning the role of FYM, due to its high level of organic $\mathrm{C}$, it was responsible for increasing soil organic carbon/matter in a short term [26]. This might be due to similar increase in soil reactions among all pure organic treatments as compared to other treatments consisting chemical fertilizer. Also, an increase in soil reactions due to the application of organic fertilizer and manure was stated by Petek [27]. The 
treatments FYM, cow urine, vermicompost and BOF showed SOM as $2.66 \%, 2.45 \%, 2.72 \%$ and $2.77 \%$ respectively whereas combination of all these organic sources resulted SOM as $2.68 \%$. Treatments with sole application of the organic sources and that with combination of organic sources had no significant differences in SOM. The recommended NPK treatment had significantly lowest SOM (2.06\%). Here, lower SOM was recorded in the treatments with inorganic NPK application. Similar studies indicated that chemical fertilizer reduces SOM stocks because it enhances soil organic matter mineralization [28,29]. This revealed that FYM, vermicompost, bio-organic fertilizer, cow urine and their combinations had positive effect on SOM. Application of organic fertilizers with or without chemical fertilizer significantly increased soil organic matter but application of inorganic fertilizer alone had no effects [30,31]. Similarly, an increase in SOM due to application of either FYM or FYM + cow urine was also reported by Veeresha., et al [32]. Such findings were also reported by Piaszczyk., et al. [33] in forest nursery soil. They found increase in organic matter by $33 \%$ - $40 \%$ in organic fertilizer applied soils in relation to the control soils. Likewise, roles of bio-fertilizers to maintain or increase the content of organic matter and improve soil fertility in arable soils

\begin{tabular}{|l|c|}
\hline \multicolumn{1}{|c|}{ Treatments } & $\begin{array}{c}\text { Soil organic } \\
\text { matter (\%) }\end{array}$ \\
\hline T1: Recommended NPK & $2.06 \mathrm{c}$ \\
\hline T2: NPK (50\%) + FYM (50\%) & $2.29 \mathrm{bc}$ \\
\hline T3: FYM & $2.66 \mathrm{ab}$ \\
\hline T4: Vermicompost & $2.72 \mathrm{a}$ \\
\hline T5: Cow urine & $2.45 \mathrm{ab}$ \\
\hline T6: Bio organic fertilizer (BOF) & $2.77 \mathrm{a}$ \\
\hline T7: 50\% FYM + 50\% cow urine & $2.70 \mathrm{a}$ \\
\hline T8: $50 \%$ FYM + 50\% vermicompost & $2.85 \mathrm{a}$ \\
\hline T9: $50 \%$ FYM + 50\% BOF & $2.83 \mathrm{a}$ \\
\hline T10: $25 \%$ FYM + 25\% Vermicompost + & $2.68 \mathrm{ab}$ \\
25\% cow urine + 25\% BOF & 0.37 \\
\hline LSD $(0.05)$ & 0.12 \\
\hline SEm $( \pm)$ & 8.2 \\
\hline CV $(\%)$ & $* *$ \\
\hline P value & \\
\hline
\end{tabular}

Table 6: Effect of different fertilizer sources on soil organic matter in Chitwan, Nepal, 2015/16.

Note: Means followed by the same letter(s) in the same column are not significantly different at $5 \%$ level of significance by DMRT.

**Represents significant at $1 \%$ level of significance. stated by Dinesh., et al. 2010 [34].

\section{Soil microbial population}

Counting the CFU and simultaneously calculating the microbial population in the given soil sample revealed that both bacteria and fungi population ranged relatively higher in the treatments with sole or combined organic fertilizer sources than in recommended NPK except bacteria population in FYM (50\%) + cow urine (50\%) treatment (Table 7 and 8$)$. The highest bacteria population $(37.6 \mathrm{x}$ $10^{6} \mathrm{cfu} / \mathrm{g}$ and $43.6 \times 10^{7} \mathrm{cfu} / \mathrm{g}$ in $10^{-5}$ and $10^{-6}$ dilutions respectively) was observed in the treatment combining all four organic fertilizer sources i.e. FYM (25\%) + vermicompost (25\%) + Cow Urine $(25 \%)+$ BOF $(25 \%)$ followed by BOF $\left(17.3 \times 10^{6} \mathrm{cfu} / \mathrm{g}\right.$ and $13.7 \mathrm{x}$ $10^{7} \mathrm{cfu} / \mathrm{g}$ in $10^{-5}$ and $10^{-6}$ dilutions respectively) (Table 7). Similar trend was observed in case of fungi population. Maximum fungi population observed was $10.0 \times 10^{5} \mathrm{cfu} / \mathrm{g}$ and $11.0 \times 10^{6} \mathrm{cfu} / \mathrm{g}$ (in $10^{-5}$ and $10^{-6}$ dilutions respectively) in the treatment FYM (25\%) + vermicompost $(25 \%)+$ Cow urine $(25 \%)+$ BOF $(25 \%)$ followed

\begin{tabular}{|c|c|c|c|c|}
\hline \multirow{3}{*}{ Treatments } & \multirow{2}{*}{\multicolumn{2}{|c|}{$\begin{array}{c}\begin{array}{c}\mathbf{1}^{\text {st }} \text { Reading } \\
\text { (after } 24 \\
\text { hrs.) }\end{array} \\
\begin{array}{c}\text { Dilution } \\
\text { factor }\end{array}\end{array}$}} & \multirow{2}{*}{\multicolumn{2}{|c|}{ 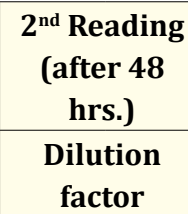 }} \\
\hline & & & & \\
\hline & $10^{-5}$ & $10^{-6}$ & $10^{-5}$ & $10^{-6}$ \\
\hline T1: Recommended NPK & $\begin{array}{l}2.45 \\
\times 10^{6}\end{array}$ & $\begin{array}{l}2.52 \times \\
10^{7}\end{array}$ & $\begin{array}{l}3.21 \mathrm{x} \\
10^{6}\end{array}$ & $\begin{array}{l}4.10 \\
x 10^{7}\end{array}$ \\
\hline $\begin{array}{l}\text { T2: NPK }(50 \%)+F Y M \\
(50 \%)\end{array}$ & $\begin{array}{l}2.8 \mathrm{x} \\
10^{6}\end{array}$ & $\begin{array}{l}2.70 \mathrm{x} \\
10^{7} \\
\end{array}$ & $\begin{array}{l}4.27 \mathrm{x} \\
10^{6}\end{array}$ & $\begin{array}{l}5.90 \\
\times 10^{7} \\
\end{array}$ \\
\hline T3: FYM & $\begin{array}{l}2.57 \\
\times 10^{6}\end{array}$ & $\begin{array}{l}3.13 \times \\
10^{7}\end{array}$ & $\begin{array}{l}4.20 x \\
10^{6}\end{array}$ & $\begin{array}{l}6.50 \\
\times 10^{7}\end{array}$ \\
\hline T4: Vermicompost & $\begin{array}{l}2.20 \\
\times 10^{6}\end{array}$ & $\begin{array}{l}3.63 \times \\
10^{7}\end{array}$ & $\begin{array}{l}3.06 \mathrm{x} \\
10^{6}\end{array}$ & $\begin{array}{l}5.17 \\
\times 10^{7}\end{array}$ \\
\hline T5: Cow urine & $\begin{array}{l}1.67 \\
\times 10^{6}\end{array}$ & $\begin{array}{l}4.9 x \\
10^{7}\end{array}$ & $\begin{array}{l}3.50 \mathrm{x} \\
10^{6}\end{array}$ & $\begin{array}{l}5.67 \\
\times 10^{7}\end{array}$ \\
\hline $\begin{array}{l}\text { T6: Bio organic fertilizer } \\
\text { (BOF) }\end{array}$ & $\begin{array}{l}12.0 \\
\times 10^{6} \\
\end{array}$ & $\begin{array}{l}7.8 x \\
10^{7} \\
\end{array}$ & $\begin{array}{l}17.3 \mathrm{x} \\
10^{6}\end{array}$ & $\begin{array}{l}13.7 \\
\times 10^{7}\end{array}$ \\
\hline $\begin{array}{l}\text { T7: } 50 \% \mathrm{FYM}+50 \% \text { cow } \\
\text { urine }\end{array}$ & $\begin{array}{l}10.9 \\
\times 10^{6}\end{array}$ & $\begin{array}{l}1.37 \mathrm{x} \\
10^{7}\end{array}$ & $\begin{array}{l}16.2 \mathrm{x} \\
10^{6}\end{array}$ & $\begin{array}{l}2.93 \\
\times 10^{7} \\
\end{array}$ \\
\hline $\begin{array}{l}\text { T8: } 50 \% \mathrm{FYM}+50 \% \\
\text { vermicompost }\end{array}$ & $\begin{array}{l}5.63 \\
\times 10^{6} \\
\end{array}$ & $\begin{array}{l}4.9 x \\
10^{7} \\
\end{array}$ & $\begin{array}{l}7.53 x \\
10^{6} \\
\end{array}$ & $\begin{array}{l}6.87 \\
\times 10^{7} \\
\end{array}$ \\
\hline T9: $50 \% \mathrm{FYM}+50 \% \mathrm{BOF}$ & $\begin{array}{l}2.60 \\
\times 10^{6} \\
\end{array}$ & $\begin{array}{l}5.36 \mathrm{x} \\
10^{7} \\
\end{array}$ & \begin{tabular}{|l|}
$3.23 \mathrm{x}$ \\
$10^{6}$ \\
\end{tabular} & $\begin{array}{l}5.77 \\
\times 10^{7} \\
\end{array}$ \\
\hline $\begin{array}{l}\text { T10: } 25 \% \mathrm{FYM}+25 \% \\
\text { Vermicompost }+25 \% \text { cow } \\
\text { urine }+25 \% \text { BOF }\end{array}$ & $\begin{array}{l}11.1 \\
\times 10^{6}\end{array}$ & $\begin{array}{l}19.4 \mathrm{x} \\
10^{7}\end{array}$ & $\begin{array}{l}37.6 x \\
10^{6}\end{array}$ & $\begin{array}{l}43.6 \\
\times 10^{7}\end{array}$ \\
\hline
\end{tabular}

Table 7: Effect of different fertilizer sources on soil bacteria opulation (cfu/g) at Rampur, Chitwan, 2015/16. 
by $7.87 \times 10^{5} \mathrm{cfu} / \mathrm{g}$ and $9.33 \times 10^{6} \mathrm{cfu} / \mathrm{g}$ (in $10^{-5}$ and $10^{-6}$ dilutions respectively) in vermicompost treatment (Table 8 ).

\begin{tabular}{|c|c|c|c|c|}
\hline \multirow[t]{3}{*}{ Treatments } & \multirow{2}{*}{\multicolumn{2}{|c|}{$\begin{array}{c}1^{\text {st }} \begin{array}{c}\text { Reading (after } 48 \\
\text { hrs.) }\end{array} \\
\text { Dilution factor } \\
\end{array}$}} & \multirow{2}{*}{\multicolumn{2}{|c|}{$\begin{array}{c}2^{\text {nd }} \text { Reading } \\
\text { (after } 72 \text { hrs.) }\end{array}$}} \\
\hline & & & & \\
\hline & $10^{-5}$ & $10^{-6}$ & $10^{-5}$ & $10^{-6}$ \\
\hline $\begin{array}{l}\text { T1: Recom- } \\
\text { mended NPK }\end{array}$ & $4.12 \times 10^{5}$ & $5.44 \times 10^{6}$ & $6.19 \times 10^{5}$ & $7.1 \times 10^{6}$ \\
\hline $\begin{array}{l}\text { T2: NPK (50\%) } \\
+ \text { FYM (50\%) }\end{array}$ & $4.33 \times 10^{5}$ & $6.14 \times 10^{6}$ & $7.0 \times 10^{5}$ & $8.0 \times 10^{6}$ \\
\hline T3: FYM & $7.33 \times 10^{5}$ & $6.0 \times 10^{6}$ & $8.33 \times 10^{5}$ & $7.33 \times 10^{6}$ \\
\hline $\begin{array}{l}\text { T4: } \\
\text { Vermicompost }\end{array}$ & $5.33 \times 10^{5}$ & $6.63 \times 10^{6}$ & $7.87 \times 10^{5}$ & $9.33 \times 10^{6}$ \\
\hline T5: Cow urine & $5.0 \times 10^{5}$ & $5.67 \times 10^{6}$ & $7.0 \times 10^{5}$ & $8.33 \times 10^{6}$ \\
\hline $\begin{array}{l}\text { T6: Bio organic } \\
\text { fertilizer (BOF) }\end{array}$ & $5.67 \times 10^{5}$ & $5.33 \times 10^{6}$ & $7.67 \times 10^{5}$ & $8.67 \times 10^{6}$ \\
\hline $\begin{array}{l}\text { T7: } 50 \% \text { FYM } \\
+50 \% \text { cow } \\
\text { urine }\end{array}$ & $4.67 \times 10^{5}$ & $4.33 \times 10^{6}$ & $7.0 \times 10^{5}$ & $7.67 \times 10^{6}$ \\
\hline $\begin{array}{l}\text { T8: } 50 \% \text { FYM + } \\
50 \% \text { vermi- } \\
\text { compost }\end{array}$ & $4.67 \times 10^{5}$ & $4.33 \times 10^{6}$ & $7.33 \times 10^{5}$ & $8.33 \times 10^{6}$ \\
\hline $\begin{array}{l}\text { T9: } 50 \% \text { FYM } \\
+50 \% \text { BOF } \\
\end{array}$ & $6.67 \times 10^{5}$ & $5.0 \times 10^{6}$ & $9.33 \times 10^{5}$ & $7.67 \times 10^{6}$ \\
\hline $\begin{array}{l}\text { T10: } 25 \% \text { FYM } \\
+25 \% \text { Ver- } \\
\text { micompost + } \\
25 \% \text { cow urine } \\
+25 \% \text { BOF }\end{array}$ & $7.0 \times 10^{5}$ & $8.33 \times 10^{6}$ & $10.0 \times 10^{5}$ & $11.0 \times 10^{6}$ \\
\hline
\end{tabular}

Table 8: Effect of different fertilizer sources on soil fungi population (cfu/g) at Rampur, Chitwan, 2015/16.

Regarding the bacteria population (Table 7), applications of FYM and cow urine resulted the population of bacteria to be $6.50 \mathrm{x}$ $10^{7} \mathrm{cfu} / \mathrm{g}$ and $5.67 \times 10^{7} \mathrm{cfu} / \mathrm{g}$ respectively whereas their combined application (FYM 50\% + cow urine 50\%) resulted the population to be $2.93 \times 10^{7} \mathrm{cfu} / \mathrm{g}$ which is the lowest value. Similarly, vermicompost and bio-organic fertilizer resulted the bacteria population to be $5.17 \times 10^{7} \mathrm{cfu} / \mathrm{g}$ and $13.7 \times 10^{7} \mathrm{cfu} / \mathrm{g}$ respectively. Combined treatments FYM (50\%) + Vermicompost (50\%) and FYM (50\%) + BOF (50\%) had bacteria population $6.87 \times 10^{7} \mathrm{cfu} / \mathrm{g}$ and $5.77 \times 10^{7}$ $\mathrm{cfu} / \mathrm{g}$ respectively. Regarding the fungi population (Table 8), applications of FYM and cow urine resulted the population of fungi to be $8.33 \times 10^{6} \mathrm{cfu} / \mathrm{g}$ and $7.33 \times 10^{6} \mathrm{cfu} / \mathrm{g}$ respectively whereas their combined application (FYM 50\% + cow urine 50\%) resulted the population to be $7.67 \times 10^{6} \mathrm{cfu} / \mathrm{g}$. Similarly, vermicompost and bio-organic fertilizer resulted the fungi population to be $9.33 \times 10^{6}$ $\mathrm{cfu} / \mathrm{g}$ and $8.67 \times 10^{6} \mathrm{cfu} / \mathrm{g}$ respectively. Combined treatments FYM $(50 \%)+$ Vermicompost (50\%) and FYM (50\%) + BOF (50\%) had fungi population $8.33 \times 10^{6} \mathrm{cfu} / \mathrm{g}$ and $7.67 \times 10^{6} \mathrm{cfu} / \mathrm{g}$ respectively.

Use of organic matter stimulates growth and development of beneficial microorganisms [35]. Although there are very few studies regarding effect of cow urine on soil microbes, significant increase in soil fungi and bacteria population over the control was reported by Veeresha., et al. [32] when applying FYM and cow urine as organic fertilizers. Soil microbial biomass is one of the most sensitive indicators of soil quality changes [36]. Even short-term application of organic manures and bio-fertilizers promoted soil microbial and enzyme activities and these parameters are sensitive enough to detect changes in soil quality [34].

In recommended NPK treatment, the bacterial population was $3.21 \times 10^{6} \mathrm{cfu} / \mathrm{g}$ and $4.10 \times 10^{7} \mathrm{cfu} / \mathrm{g}$ in $10^{-5}$ and $10^{-6}$ dilution respectively. But it ranged from $3.06 \times 10^{6} \mathrm{cfu} / \mathrm{g}$ to $37.6 \times 10^{6} \mathrm{cfu} / \mathrm{g}$ and $2.93 \times 10^{7} \mathrm{cfu} / \mathrm{g}$ to $43.6 \times 10^{7} \mathrm{cfu} / \mathrm{g}$ in $10^{-5}$ and $10^{-6}$ dilutions respectively for the treatments consisting organic fertilizers sources. Similarly, fungi population in recommended NPK treatment was $6.19 \times 10^{5} \mathrm{cfu} / \mathrm{g}$ and $7.1 \times 10^{6} \mathrm{cfu} / \mathrm{g}$ in $10^{-5}$ and $10^{-6}$ dilutions respectively. But it ranged from $7.0 \times 10^{5} \mathrm{cfu} / \mathrm{g}$ to $10.0 \times 10^{6} \mathrm{cfu} / \mathrm{g}$ and $7.33 \times 10^{5} \mathrm{cfu} / \mathrm{g}$ to $11.0 \times 10^{6} \mathrm{cfu} / \mathrm{g}$ in $10^{-5}$ and $10^{-6}$ dilutions respectively for the treatments consisting organic fertilizers sources. This showed that soil microbial population were higher in organic treatments as compared to inorganic treatments. Lower microbial population in the soil might be attributed to the enhanced acidity caused by chemical fertilization which is unfavorable for microbes' growth and development e.g. Actinomycetes [37]. Addition of organic amendments such as manures results in increased microbial biomass (soil bacteria and fungi) and higher microbial activity in the soil [38]. Likewise, Shi-wei and Fuzhen [39] emphasized that organic fertilizer sources have greatly increased surface areas providing more microsites for microbial decomposing organisms, and strong adsorption and retention of nutrients thereby supporting for increment of the soil microbes.

Many studies had shown that soil microbial biomass and communities are changed by organic fertilizer sources and these 
changes may relate to soil organic carbon/matter content [40]. Positive linear regression was found in between SOM and bacteria population $\left(R^{2}=0.0342\right.$, Figure 2$)$ and that in between SOM and fungi population $\left(\mathrm{R}^{2}=0.112\right.$, Figure 3$)$. A positive linear regression relationship between microbial diversity and soil organic carbon suggested that increase in microbial biomass and functional diversity might be due to increase in carbon availability resulting from manure amendments [41].

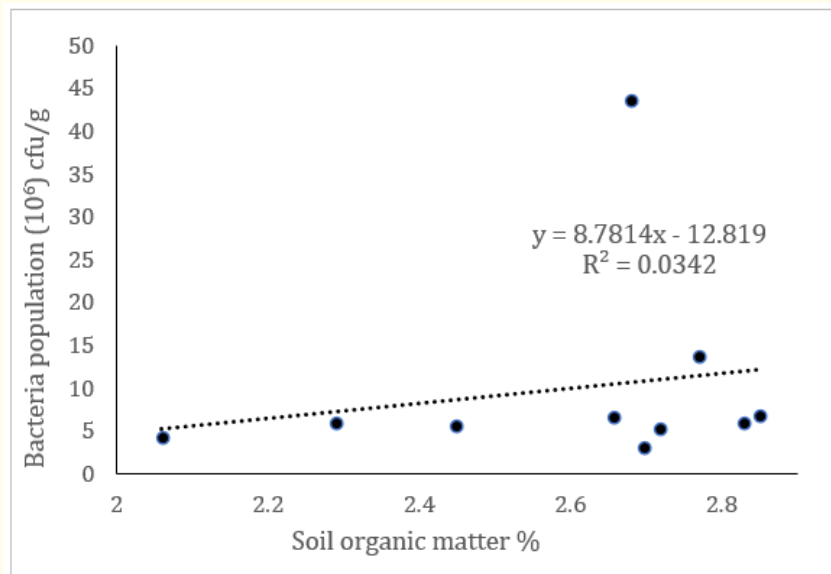

Figure 2: Linear regression between soil organic material and bacterial population.

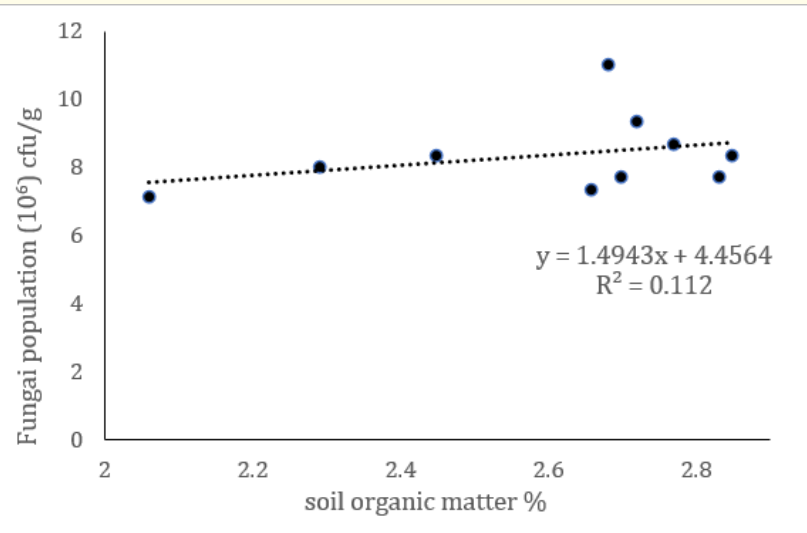

Figure 3: Linear regression between soil organic material and fungi population.

\section{Conclusion}

The organic fertilizer sources enriched the organic matter content in the soil thereby enhancing the soil fungi and bacteria population. Combining all the organic sources i.e. farmyard manure $(25 \%)+$ vermicompost $(25 \%)+$ bio-organic fertilizer $(25 \%)+$ cow urine $(25 \%)$ resulted the maximum population of soil bacteria and fungi and combining farmyard manure $50 \%$ + vermicompost $50 \%$ ensured the highest organic matter content in the soil.

\section{Bibliography}

1. Michaud DS., et al. "Intakes of fruits and vegetables, carotenoids and vitamins $\mathrm{A}, \mathrm{E}, \mathrm{C}$ in relation to the risk of bladder cancer in the ATBC cohort study". British Journal of Cancer 87 (2002): 960-965.

2. Zhao H., et al. "Dietary isothiocyanates, GSTM1, GSTT1, NAT2 polymorphisms and bladder cancer risk". International Journal of Cancer 120 (2007): 2208-2213.

3. Whitman WB., et al. "Prokaryote: the unseen majority". Proceedings of the National Academy of Sciences 95 (1998): 65786583.

4. Soil bacteria.

5. Grayston SJ., et al. "Selective influence of plant species on microbial diversity in the rhizosphere". Soil Biology and Biochemistry 30 (1998): 369-378.

6. Marschner P., et al. "Soil and plant specific effects on bacterial community composition in the rhizosphere". Soil Biology and Biochemistry 33 (2001): 1437-1445.

7. Vieira FCS and Nahas E. "Comparison of microbial numbers in soils by using various culture media and temperatures". Microbiological Research 160 (2005): 197-202.

8. Bonkowski M., et al. "Rhizosphere fauna: The functional and structural diversity of intimate interactions of soil fauna with plant roots". Plant and Soil 321 (2009): 213-233.

9. Bais HP., et al. "The role of root exudates in rhizosphere interactions with plants and other organisms". Annual Review of Plant Biology 57 (2006): 233-266. 
10. Dauda SN., et al. "Growth and yield of water melon (Citrullus lanatus) as affected by poultry manure application". Electronic Journal of Environmental, Agricultural and Food Chemistry 4 (2008): 305-311.

11. Suresh KD., et al. "Microbial biomass carbon and microbial activities of soils receiving chemical fertilizers and organic amendments". Archives of Agronomy and Soil Science 50 (2004): 641-647.

12. Arancon NQ., et al. "Effect of vermicomposts produced from cattle manure, food waste and paper waste on the growth and yield of peppers in the field". Pedobiologia 49 (2005): 297-306.

13. Coleman DC., et al. "Biological strategies of nutrient cycling in soil systems". Annual Review of Ecological Systems 13 (1983): 1-56.

14. Marumoto T., et al. "Mineralization of nutrients from soil microbial biomass". Soil Biology and Biochemistry 14 (1982): 469475.

15. MoAD. "Agriculture Diary". Ministry of Agriculture Development, Kathmandu, Nepal (2015).

16. Hamdine S. "Heavy metal traces in potatoes and cabbages fertilized with human urine and composted faeces". M. Sc. Thesis. University of Applied Sciences. Switzerland 45 (2008).

17. Sharma R., et al. "Effects of cattle urine and FYM on yield of broccoli and soil properties". Journal of Agri-Search 3 (2016):157160.

18. Schoeneberger PJ., et al. "Field book for describing and sampling soils, Version 3.0". Natural Resources Conservation Service, National Soil Survey Center, USDA (2012): 4-8.

19. Jaishy SN. "Current fertility status of Nepal and IPNS". In: Jaishy SN, Mandal SN, Subedi TB, Subedi KS and Weber G (Eds.). Component of integrated plant (2000) 63-72.

20. Serial dilution and microbial counting.

21. Fahy PC and Persley GJ. "Plant Bacterial Diseases, A Diagnostic Guide”. Academic Press, NY (1983).

22. Tuite J. "Plant pathological methods: Fungi and bacteria". Burgess Publishing Company, USA (1969).
23. Microbiologic Dilutions Guide.

24. Haynes RJ. "Labile organic matter fractions as central components of the quality of agricultural soils: an overview". Advances in Agronomy 85 (2005): 221-268.

25. Lal R. "Sequestering carbon in soils of agro-ecosystems". Food Policy 36 (2011): 533-539.

26. Elzobair KA., et al. "Contrasting effects of biochar verse manure on soil microbial communities and enzyme activities in an Aridisol". Chemosphere 142 (2016): 145-152.

27. Petek M., et al. "Leaf Content of Macro and Microelements in Vitis vinifera cv. Sauvignon Blanc". VI International ISHS Symposium on Mineral Nutrition on Fruit Crops, Portugal (2008).

28. Mulvaney RL., et al. "Synthetic nitrogen fertilizers deplete soil nitrogen: a global dilemma for sustainable cereal production". Journal of Environmental Quality 38 (2009): 2295-2314.

29. Russell AE., et al. "Nitrogen fertilizer effects on soil carbon balances in Midwestern US agricultural systems". Ecological Applications 19 (2009): 1102-1113.

30. Zane FL and Basil DD. "Residual effects of dairy cattle manure on plant growth and soil properties". Agronomy Journal 72 (1980): 123-130.

31. Theodora M., et al. "Effects of injected liquid cattle manure on growth and yield of winter wheat and soil characteristics". Agronomy Journal 95 (2003): 592-560.

32. Veeresha S and Gopakkali P. "Effect of organic production practices on yield and soil health of irrigated maize (Zea mays L.) as influenced by various levels of FYM and cattle urine application". Environment and Ecology 32 (2014): 627-630.

33. Piaszczyk W., et al. "Study on the effect of organic fertilizers on soil organic matter and enzyme activities of soil in forest nursery". Soil Science Annual 68.3 (2017): 125-131.

34. Dinesh R., et al. "Short-term incorporation of organic manures and biofertilizers influences biochemical and microbial characteristics of soils under an annual crop; Turmeric (Curcuma longa L.)". Bioresource Technology 101 (2010): 4697-4702.

35. Kaur K., et al. "Impact of organic manures with and without mineral fertilizers on soil chemical and biological properties 
under tropical conditions". Journal of Plant Nutrition and Soil Science 168 (2005): 117-122.

36. Liu ZJ., et al. "Soil quality assessment of yellow clayey paddy soils with different productivity". Biology and Fertility of Soils 50 (2014): 537-548.

37. Zhang XY., et al. "Responses of absolute and specific soil enzyme activities to long term additions of organic and mineral fertilizer". Science of the Total Environment 536 (2015): 59-67.

38. Bunemann EK, et al. "Impact of agricultural inputs on soil organisms- a review". Australian Journal of Soil Research 44 (2006): 379-406.

39. Shi-wei $\mathrm{Z}$ and Fuzhen H. "The nitrogen uptake efficiency from $15 \mathrm{~N}$ labelled chemical fertilizer in the presence of earthworm manure (cast)". In: Veeresh GK, D Rajagopal and CA Viraktamath (editions) Advances in Management and Conservation of Soil Fauna. Oxford and IBH publishing Co., New Delhi (1991): 539-542.

40. Ai C., et al. "The alleviation of acid soil stress in rice by inorganic and organic ameliorants is associated with changes in soil enzyme activity and microbial community composition". Biology and Fertility of Soils 51 (2015): 465-477.

41. Gomez E., et al. "Soil bacterial functional diversity as influenced by organic amendment application". Bio Resource Technology 97 (2006): 1484-1489.

\section{Assets from publication with us}

- Prompt Acknowledgement after receiving the article

- Thorough Double blinded peer review

- Rapid Publication

- Issue of Publication Certificate

- High visibility of your Published work

Website: www.actascientific.com/

Submit Article: www.actascientific.com/submission.php

Email us: editor@actascientific.com

Contact us: +919182824667

Citation: Salina Panta., et al."Effect of Fertilizer Sources on Soil Organic Matter and Soil Microbial Population in Broccoli Field". Acta Scientific Agriculture 4.6 (2020): 36-44. 